\title{
Soluble interleukin-6 receptors in inflammatory bowel disease: relation to circulating interleukin-6
}

K Mitsuyama, A Toyonaga, E Sasaki, O Ishida, H Ikeda, O Tsuruta, K Harada, H Tateishi, T Nishiyama, K Tanikawa resulting in the formation of high affinity IL-6 binding sites and transduction of the signal.

A soluble form of IL-6R with a molecular weight of $50-55 \mathrm{kDa}$ was recently found in human serum and urine. ${ }^{13} 14$ Furthermore, genetically engineered soluble (s) IL-6R could associate with gp 130 on the cell surface in the presence of IL-6, and this molecule lacking transmembrane and cytoplasmic domains could also transduce the IL-6 signal. ${ }^{11}$ These findings suggest that sIL-6R plays an important role as a naturally occurring enhancer of IL-6 action in vivo. However, little is known about the profile of sIL-6R in human diseases. ${ }^{14} \mathrm{~A}$ new double ligand enzyme linked immunosorbent assay (ELISA) allowed us to measure this circulating form of IL-6 receptor. To our knowledge, this is the first report of in vivo levels of sIL-6R in inflammatory bowel disease.

\section{Methods}

\section{SUBJECTS}

Thirty two patients with ulcerative colitis and 24 with Crohn's disease were investigated. The diagnoses were based on characteristic clinical, endoscopic, radiological, and histological features.

\section{Patients with ulcerative colitis}

There were 17 men and 15 women, with a median age of 32 years (range 15-68 years) and a median disease duration of 3 years (range 1-20 years). In terms of disease distribution, 19 patients had pancolitis, nine had left colon involvement, and four had disease limited to the rectum. Disease activity in each patient was analysed according to the criteria of Truelove and Witts. ${ }^{15}$ Sixteen patients suffered from active disease (six mild, eight moderate, two severe), and 16 had inactive disease. At the time of study, three patients were receiving corticosteroids only, 14 corticosteroids plus sulphasalazine, eight sulphasalazine only, and seven no specific treatment.

SMI Bristol Limited, Research and Development Section, Sagamihara,

Kanagawa, Japan

O Ishida

Correspondence to: Dr K Mitsuyama, Second Department of Medicine, Kurume University School of Medicine, 67 Ashai-machi, Kurume, Fukuoka 830, Japan.

Accepted for publication 12 April 1994
Interleukin (IL)-6 is a pleiotropic cytokine with central roles in the regulation of inflammatory and immune reactions. ${ }^{12}$ Recently $w^{34}$ and other groups ${ }^{5-8}$ described the kinetics of the appearance of IL-6 in blood and tissue from patients with inflammatory bowel disease, and have suggested that IL-6 is related to the pathophysiology of this disease.

Since IL-6 responses are mediated by specific membrane receptors on target cells, ${ }^{9-11}$ the IL-6 receptor could be very important in modulating the actions of IL-6 in vivo, especially where immunopathogenesis is associated with IL-6. The IL-6 receptor (R) system is composed of two functionally different chains: an $80 \mathrm{kDa}$ ligand binding chain, known as IL-6R, and a $130 \mathrm{kDa}$ non-ligand binding but signal transducing chain, gp130. ${ }^{12}$ gp130 is associated with complexes of IL-6 and IL-6R,

\section{Patients with Crohn's disease}

There were 14 men and 10 women, with a median age of 27 years (range 18-66 years) and a median disease duration of 2 years (range 1-14 years). In 21 patients the disease affected both the ileum and the colon, in one patient the colon, and in two the ileum. Disease activity was assessed by the score of the 
International Organisation for the Study of Inflammatory Bowel Disease (IOIBD). ${ }^{16} \mathrm{~A}$ score of 1 or less was defined as corresponding to inactive disease and one of 2 or more to active disease. In this group, 15 patients had active disease, and nine inactive disease. Two patients had taken corticosteroids alone, one both corticosteroids and sulphasalazine, five sulphasalazine alone, and 16 no specific treatment.

\section{Control subjects}

Sixty nine healthy, age and sex matched subjects served as normal controls for the sIL-6R assay. Ten patients with other colitides (five infectious and five ischaemic colitis) in the acute stage were examined as disease controls.

\section{SIL-6R ELISA}

A double ligand ELISA (SMI Bristol Ltd, Kanagawa, Japan) was developed for quantitative determination of sIL-6R by modifying procedures described previously. ${ }^{14} 17$ Briefly, 96-well microtitre plates (Maxisorp F96, Nunc, Roskilde, Denmark) were coated overnight at $4^{\circ} \mathrm{C}$ with $100 \mu \mathrm{l} /$ well purified antiIL-6R (MT18, ${ }^{18} 2 \mu \mathrm{g} / \mathrm{ml}$ in $10 \mathrm{mM}$ phosphate buffer, pH 7.0). Non-specific binding was blocked with $1 \%$ bovine serum albumin (BSA, fraction V, Sigma Chemical Co, St Louis, MO, USA) in $50 \mathrm{mM}$ Tris- $\mathrm{HCl}$ buffered saline (TBS) for three hours at room temperature. Plates were rinsed with TBS containing $0.05 \%$ Tween 20 , and $20 \mu \mathrm{l}$ of sample diluted 1:5 in $0 \cdot 1 \%$ BSA-TBS were added, followed by incubation for two hours at room temperature. Plates were washed and $1 \mu \mathrm{g} / \mathrm{ml}$ of biotinylated guinea pig anti-IL-6R $(\alpha \mathrm{GV} 6 \mathrm{R})^{19}$ was added for two hours at room temperature. Plates were washed again, $100 \mu \mathrm{l} /$ well streptavidin-horseradish peroxidase (ZYMED Laboratories Inc, South San Francisco, CA, USA) was added, and the plates were incubated for 30 minutes at room temperature.

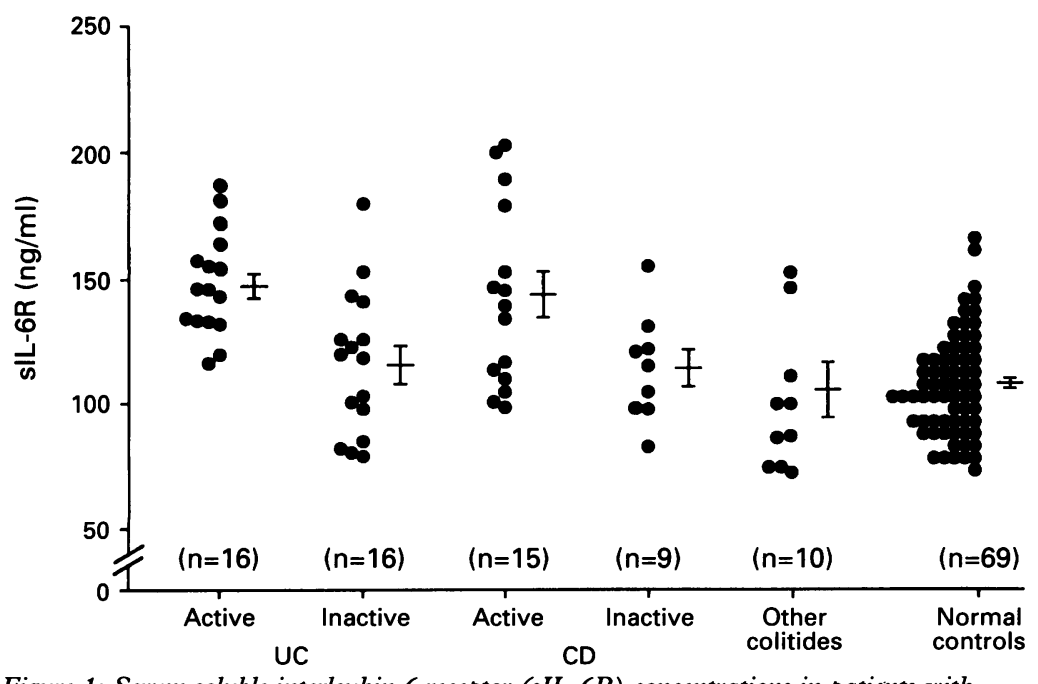

Figure 1: Serum soluble interleukin 6 receptor (sIL-6R) concentrations in patients with active and inactive inflammatory bowel disease, in patients with other colitides, and in normal subjects. The sIL-6R concentration was measured by ELISA. Active ulcerative colitis (UC): $p<0.01 \mathrm{v}$ inactive UC $p<0.001 \mathrm{v}$ other colitides, $p<0.001 \mathrm{v}$ normal controls; active Crohn's disease (CD): $p<0.05 \mathrm{v}$ inactive $C D p<0.01 \mathrm{v}$ other colitides, $p<0.001 \mathrm{v}$ normal controls.
After washing again, substrate solution ( $1 \mathrm{mg} / \mathrm{ml}$ of o-phenylenediamine, $0.03 \% \mathrm{H}_{2} \mathrm{O}_{2}$ in $0.1 \mathrm{M}$ citrate phosphate buffer, $\mathrm{pH} 5.0$ ) was added. The plates were incubated for 10 minutes and the reaction was terminated with $100 \mu \mathrm{l} /$ well of $1 \mathrm{~N} \mathrm{H}_{2} \mathrm{SO}_{4}$ solution. The absorbance was then measured at $492 \mathrm{~nm} /$ $630 \mathrm{~nm}$. Purified sIL-6R from the supernatant of $\mathrm{CHO}-\mathrm{CN}$ cells ${ }^{19}$ was used as a reference reagent. Intra-assay and interassay replicates gave results with coefficients of variation of less than $3.5 \%$ and $4 \cdot 8 \%$, respectively. The mean (SEM) recovery of sIL-6R from serum was $97 \cdot 3(1 \cdot 7) \%$. Sample titration gave detectable levels of sIL-6R that always followed the standard curve.

\section{DETERMINATION OF IL-6 AND OTHER}

\section{LABORATORY PARAMETERS}

ELISA methods were used to assay IL-6 (SRL Inc, Tokyo, Japan) ${ }^{3} 4$ and sIL-2R (Immunotech SA, France). C-reactive protein was measured by laser nephelometry (NA Latex CRP kit, Hoechst Japan, Tokyo, Japan). Levels of immunoglobulins were quantitated by radial immunodiffusion. Total leukocyte counts, platelet counts, erythrocyte sedimentation rates, serum total protein levels, and protein electrophoresis profiles were determined according to established techniques.

\section{GEL FILTRATION ANALYSIS}

Chromatographic procedures were carried out on a fast protein liquid chromatography (FPLC) system (Pharmacia, Sweden). Each serum sample was fractionated by gel filtration through a Superose 6 HR 10/30 column equilibrated with $20 \mathrm{mM}$ phosphate buffer, $\mathrm{pH} 7 \cdot 5$, and $50 \mathrm{mM} \mathrm{NaCl}$. Each sample $(90 \mu \mathrm{l})$ was eluted with a buffer flow rate of $0.3 \mathrm{ml} / \mathrm{min}$. Fractions of $0.6 \mathrm{ml}$ were collected and immunoreactive IL-6 and sIL-6R levels in each fraction were measured by ELISA. Also, $\alpha 2$-macroglobulin levels in these fractions were determined by laser nephelometry (BehringWerke AG, Marburg, Germany). The column was calibrated with marker proteins of known molecular weight.

\section{LS-ELISA FOR IL-6-SIL-6R COMPLEXES}

The ELISA method used to detect bound complexes of IL-6 and sIL-6R followed the general principles for luminescence sandwich (LS)-ELISA. ${ }^{20}$ In brief, ELISA wells were coated with rabbit polyclonal antibody against IL-6 $(2 \mu \mathrm{g} / \mathrm{ml}$ in carbonate buffer, $\mathrm{pH} 8 \cdot 5)$. After blocking with $1 \% \mathrm{BSA}, 100 \mu \mathrm{l}$ of sample was added and incubated for two hours at room temperature. Plates were washed, and $100 \mu \mathrm{l}$ of biotinylated MT18 $(1 \mu \mathrm{g} / \mathrm{ml})$, as the detecting antibody, was added for two hours at room temperature. Plates were then washed and incubated with streptavidin-alkaline phosphatase (Bethesda Research Laboratories, Gaithersburg, MD, USA) at a dilution of 1:6000 for 30 minutes at room temperature. After washing again, LUMI-PHOS (Lumigen 

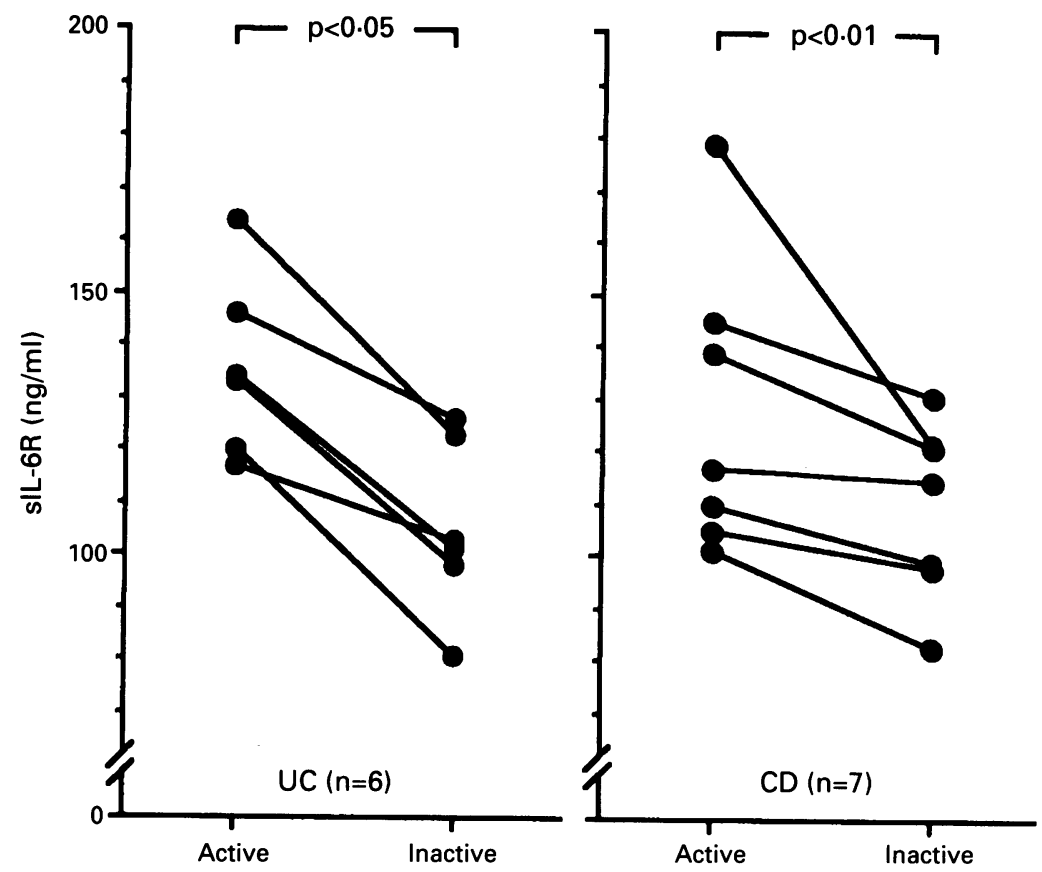

Figure 2: Serial soluble interleukin 6 receptor (sIL-6R) concentrations in patients with ulcerative colitis (UC) and Crohn's disease (CD). Paired serum samples were obtained during active and inactive stages of disease and assayed for sIL-6R by ELISA.

Inc, Detroit, MI, USA) was added to each well. Luminescence intensity was measured with a luminescence reader (ML1000, Dynatech Laboratories Inc, Chantilly, VA, USA).

STATISTICAL ANALYSIS

Student's $t$ test was used for normally distributed data. The Wilcoxon test for paired data was used for data that were not normally distributed. The means of multiple groups were compared by Scheffé's test after analysis of variance (ANOVA). For correlation analysis, Spearman's rank correlation was used. Any $p$ value of less than 0.05 was considered to indicate a significant difference.

\section{Results}

Individual serum concentrations of sIL-6R are shown in Figure 1. Detectable sIL-6R concentrations were found in serum from every subject. sIL-6R values in patients with active

Correlation coefficients and significance values between laboratory parameters and serum soluble interleukin 6 receptor (sIL-6R) and interleukin $6(I L-6)$ concentrations in patients with ulcerative colitis (UC) and Crohn's disease (CD)

\begin{tabular}{|c|c|c|c|c|}
\hline & \multicolumn{2}{|c|}{$s I L-6 R$} & \multicolumn{2}{|l|}{$I L-6$} \\
\hline & $U C$ & $C D$ & $U C$ & $C D$ \\
\hline Leukocyte counts & $0 \cdot 28$ & $0 \cdot 16$ & $0.60 \dagger$ & $0 \cdot 74$ \\
\hline $\begin{array}{l}\text { Platelet counts } \\
\text { Erythrocyte sedimentation }\end{array}$ & 0.03 & $0 \cdot 26$ & $0 \cdot 25$ & $0 \cdot 71^{\star}$ \\
\hline $\begin{array}{l}\text { Erythrocyte sedimentation } \\
\text { rate at } 1 \mathrm{~h}\end{array}$ & 0.29 & 0.53 & $0.55 \ddagger$ & 0.75 \\
\hline Serum C-reactive protein & $0 \cdot 23^{\star}$ & $0 \cdot 56^{\star}$ & $0.85 t$ & 0.725 \\
\hline Serum $\alpha_{2}$ globulin & $0 \cdot 40^{\star}$ & 0.40 & $0.71 \ddagger$ & $0.58^{\star}$ \\
\hline Serum IgA & $0 \cdot 31$ & $0 \cdot 50$ & $0 \cdot 14$ & 0.38 \\
\hline Serum IgM & $0 \cdot 20$ & 0.05 & 0.09 & 0.06 \\
\hline Serum IgG & $0 \cdot 60^{\star}$ & $0 \cdot 27$ & 0.03 & $0 \cdot 10$ \\
\hline Serum sIL-2R & 0.38 & 0.41 & 0.68 & $0.81 \dagger$ \\
\hline
\end{tabular}

The numbers presented are the correlation coefficients ( $r$ values) between the laboratory tests indicated in the left column and serum sIL-6R or IL-6 concentrations. ${ }_{\star} \mathrm{p}<0.05 ; \mathrm{tp}<0.01 ; \neq \mathrm{p}<0.005 ; \mathrm{Qp}<0.001$. disease (ulcerative colitis $148 \cdot 4(5 \cdot 1)$, Crohn's disease $142.3(9 \cdot 3) \mathrm{ng} / \mathrm{ml}$, mean (SEM)) were significantly increased compared to values in patients with inactive disease (ulcerative colitis $116.2(7 \cdot 2)$, Crohn's disease $114 \cdot 3$ $(7 \cdot 1) \mathrm{ng} / \mathrm{ml})$, some other type of colitis $(104 \cdot 8$ $(11 \cdot 6) \mathrm{ng} / \mathrm{ml})$, or in normal subjects $(107 \cdot 3$ $(2 \cdot 4) \mathrm{ng} / \mathrm{ml})$. sIL-6R concentrations during both active and inactive phases of disease are presented in Figure 2. After starting therapy, the serum sIL-6R concentration decreased significantly in every patient with both forms of disease. In parallel, we determined serum IL-6 concentrations in the same patients. IL-6 values were also significantly higher in patients with active disease (ulcerative colitis $9 \cdot 5(8.6)$ $(\mathrm{n}=16)$, Crohn's disease $16.0(11 \cdot 7) \mathrm{pg} / \mathrm{ml}$ $(n=15))$ than in those with inactive disease (ulcerative colitis $4.3(1 \cdot 0)(n=16)$, Crohn's disease $5.4(4 \cdot 1) \mathrm{pg} / \mathrm{ml}(\mathrm{n}=9) ; \mathrm{p}<0.05$ for both). There was, however, no correlation between serum sIL-6R and IL-6 concentrations in either ulcerative colitis or Crohn's disease patients. The Table summarises the correlation coefficients and significance values between the indicated laboratory parameters and serum sIL-6R and IL- 6 concentrations.

Figure 3 shows the representative elution profiles of IL- 6 and sIL-6R immunoreactivities in sera from patients with active ulcerative colitis and Crohn's disease. Two major peaks and some minor peaks of IL-6 immunoreactivity were seen consistently: one major peak was eluted in fractions corresponding to 25-35 kDa, whereas another peak was found at $150 \mathrm{kDa}$. Furthermore, a single immunoreactive sIL-6R peak was identified that seemed to elute together with the $150 \mathrm{kDa}$ IL-6 peak. There was, however, only a minor or no peak corresponding to IL-6 that coeluted with $\alpha 2$-macroglobulin.

To confirm the in vivo presence of the IL-6sIL-6R complex, we developed a specific LSELISA. As shown in Figure 4, luminescence exceeding the background level was observed in fractionated sera corresponding to the 150 $\mathrm{kDa}$ peak as mentioned above and as observed for the bound complex of their recombinant forms.

\section{Discussion}

This study showed that excess sIL-6R circulates in patients with active inflammatory bowel disease. Simultaneous determination of IL-6 concentrations showed that it was also raised during the active phase, as reported recently by our group. ${ }^{34}$ These dynamic changes prompted us to speculate that circulating sIL-6R may affect the bioavailability of its ligand during inflammation.

Several cytokine receptors, including those for IL-2 and tumour necrosis factor $\alpha$, exist in soluble form in the circulation and can block the cellular actions of their cognate cytokines. $^{21-23}$ Interestingly, the opposite situation arises for IL-6. A genetically engineered sIL-6R augmented the IL- 6 induction of acute phase proteins such as $\alpha 1$-antichymotrypsin and haptoglobin in human 


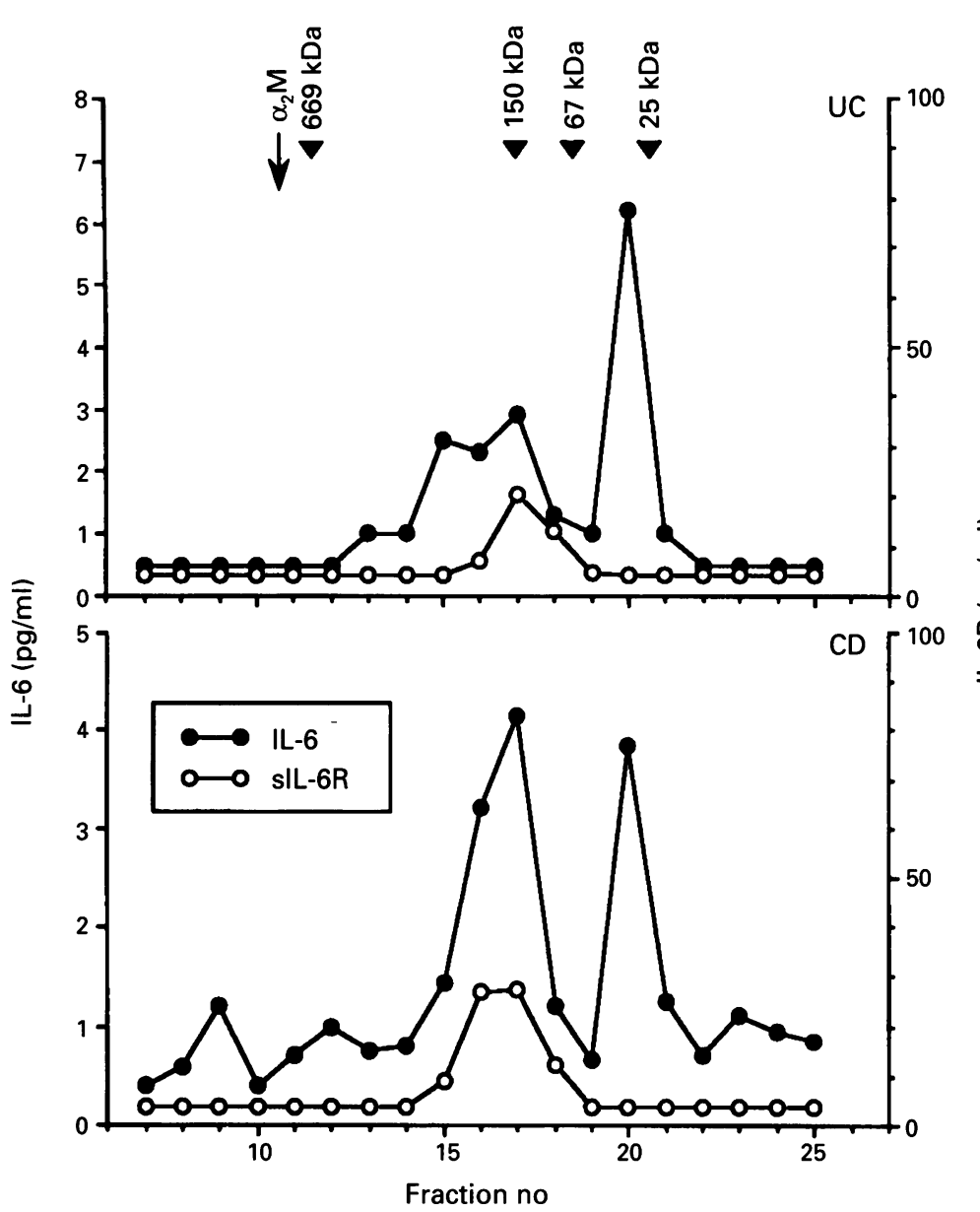

Figure 3: FPLC gel filtration chromatography of serum from patients with ulcerative colitis (UC) and Crohn's disease (CD) during the active phase. Fractions were assayed for interleukin 6 (IL-6) and soluble interleukin 6 receptor (sIL-6R) concentrations by ELISA. The points represent the mean of duplicate analyses. The elution profiles of the molecular markers thyroglobulin $(669 \mathrm{kDa}), \operatorname{IgG}(150 \mathrm{kDa})$, bovine serum albumin $(67 \mathrm{kDa})$, and chymotrypsinogen $A(25 \mathrm{kDa})$ are indicated by arrow heads. The single peak corresponding to serum $\alpha_{2}$-macroglobulin $\left(\alpha_{2} M\right)$, as measured by laser nephelometry, is marked by the arrow. The results are representative for six patients studied (ulcerative colitis, $n=4$; Crohn's disease, $n=2$ ).

hepatoma cells (HepG2) at both the mRNA and protein level. ${ }^{24} 25$ Also, it enhanced the growth inhibitory effect of IL-6 on mouse myeloleukemic cells. ${ }^{12}$ These indicate sIL-6R

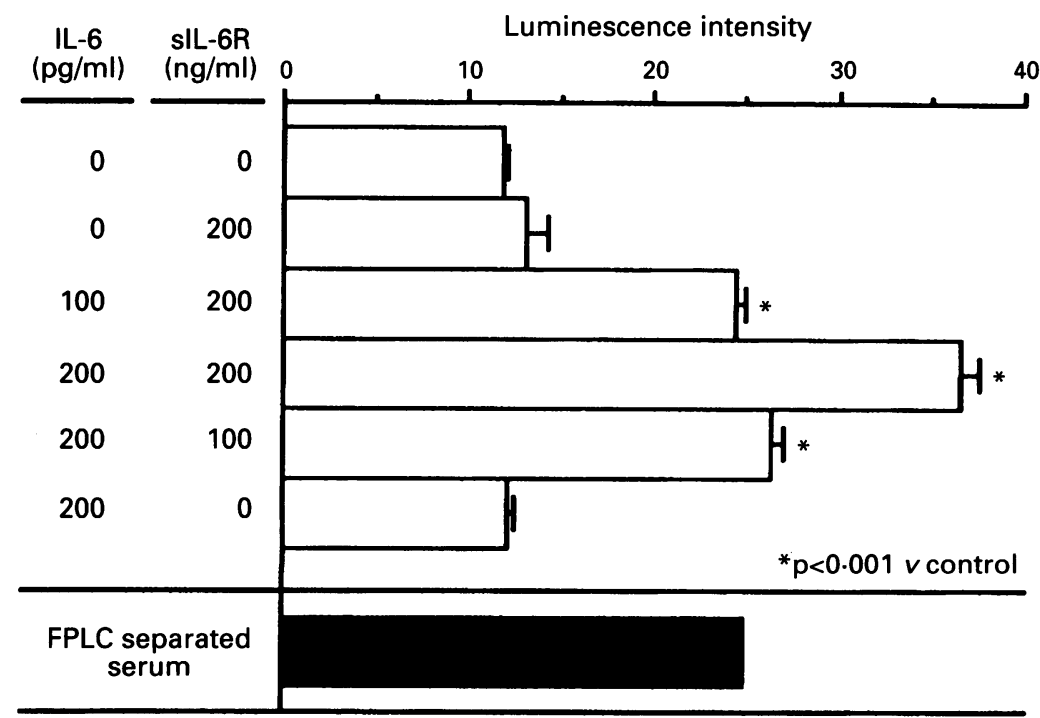

Figure 4: Detection of the bound complex of interleukin 6 (IL-6) and soluble interleukin 6 receptor (sIL-6R) by LS-ELISA. Various combinations of recombinant human IL-6 $(0-200 \mathrm{pg} / \mathrm{ml})$ and sIL-6R $(0-200 \mathrm{ng} / \mathrm{ml})$ were preincubated at $37^{\circ} \mathrm{C}$ for 30 minutes. These samples or FPLC separated serum fractions (fraction no 15-17) were assayed as described in Methods. Open bar represents the mean (SD) $(n=5)$. The data represent three patients: two with ulcerative colitis and one with Crohn's disease. may act as an agonist of IL-6-mediated cell responses. It remains unknown whether sIL-6R enhances all IL-6 functions. The positive correlations between serum levels of $\mathrm{C}$ reactive protein and sIL-6R as well as IL-6 itself seen in this study support such an effect of sIL-6R.

To analyse linkage in vivo between IL- 6 and sIL-6R, we observed the elution profile for both molecules by gel filtration. Of particular note is the finding that a substantial proportion of IL-6 coelutes with sIL-6R at the fraction corresponding to approximately $150 \mathrm{kDa}$, suggesting that the two molecules circulate as a complex. This was further confirmed by a newly developed LS-ELISA, which specifically detects complexes of the two molecules. The molecular weight of this complex, $150 \mathrm{kDa}$, is greater than expected, given the molecular weight of each component. Therefore, other molecules such as soluble gp $130^{26}$ or autoantibodies against IL- $6^{27} 28$ may comprise part of this complex in vivo. $\alpha 2-$ Macroglobulin is a serum protein of approximately $718 \mathrm{kDa}$ that can bind several cytokines such as IL-1 and IL-6. ${ }^{29} 30$ We found only trace amounts of IL-6 coeluting with this serum protein, however. These results substantiate further the importance of sIL-6R as a major IL-6-binding protein. Moreover, the existence of heterogeneous forms of circulating IL- 6 would explain, at least partially, the lack of correlation between sIL-6R and IL-6 serum levels.

The cellular source of naturally occurring sIL-6R is currently speculative. Recent in vitro studies suggest that sIL-6R is generated in culture supernatants of IL-6R bearing cells by proteolytic cleavage of cell surface IL-6 receptors. ${ }^{111417}$ However, other distinct mechanisms, including alternative splicing of the primary RNA transcript, can not be excluded. ${ }^{11}$

Somewhat surprisingly, we found no correlation between sIL-6R and sIL-2R serum levels, which were previously shown to be raised in inflammatory bowel disease patients. ${ }^{31}$ This may be explained by differences in release patterns between these two factors. Furthermore, sIL-6R may be released by T-lymphocytes, B-lymphocytes, and monocytes, ${ }^{14} 17$ whereas sIL-2R is almost exclusively derived from T-lymphocytes. ${ }^{22}$ The fact that both markers were detected at high levels, however, is further evidence that lymphocyte activation is a feature of inflammatory bowel disease. In addition, it may be of interest that there was a high correlation between IL-6 and sIL-2R serum levels in Crohn's disease since better relevant markers of disease activity in Crohn's disease are in great need.

In conclusion, our data indicate that the sIL-6R released systemically during inflammation may function as a powerful enhancer of IL-6-dependent immune processes. From a practical point of view, combined measurement of IL-6 and sIL-6R, rather than IL-6 alone, will provide an additional important parameter of IL- 6 effects in vivo.

We thank Drs Tadamitsu Kishimoto and Tetsuya Taga (Osaka University, Osaka, Japan) for their excellent assistance; and 
Tosoh Corporation, Biotechnology Research Laboratory (Kanagawa, Japan) for providing anti-IL-6 and anti-IL-6R antibodies, and recombinant IL-6 and sIL-6R

1 Kishimoto T. The biology of interleukin 6. Blood 1989; 74: $1-10$.

2 Le JM, Vilcek J. Interleukin 6. A multifunctional cytokine regulating immune reactions and the acute phase protein response. Lab Invest 1989; 61: 588-602.

3 Mitsuyama K, Sasaki E, Toyonaga A, Ikeda H, Tsuruta O, Irie A, et al. Colonic mucosal interleukin-6 in inflammatory bowel disease. Digestion 1991; 50: 104-11.

4 Mitsuyama K, Sata M, Tanikawa K. Significance of interleukin-6 in patients with inflammatory bowel disease. Gastroenterol fpn 1991; 26: 20-8.

5 Mahida YR, Kurlac L, Gallagher A, Hawkey CJ. High circulating concentrations of interleukin- 6 in active Crohn's disease but not ulcerative colitis. Gut 1991; 32: 1531-4.

6 Gross V, Andus T, Caesar I, Roth M, Schölmerich J Evidence for continuous stimulation of interleukin- 6 production in Crohn's disease. Gastroenterology 1992; 102: 514-9.

7 Stevens C, Walz G, Singaram C, Lipman ML, Zanker B, Muggia A, et al. Tumor necrosis factor- $\alpha$, interleukin- $1 \beta$, and interleukin- 6 expression in inflammatory bowel and interleukin-6 expression in in
disease. Dig Dis Sci 1992; 37: 818-26.

8 Isaacs KL, Sartor B, Haskill S. Cytokine messenger RNA profiles in inflammatory bowel disease mucosa detected by polymerase chain reaction amplification Gastroenterology 1992; 103: 1587-9.

9 Foxwell BMJ, Barrett K, Feldmann M. Cytokine receptors: Structure and signal transduction. Clin Exp Immuno 1992; 90: 161-9.

10 Kishimoto $T$, Akira $S$, Taga $T$. Interleukin-6 and its receptor: A paradigm for cytokines. Science 1992; 258 593-7.

11 Taga $T$, Hibi $M$, Murakami $M$, Saito $M$, Yawata $H$, Narazaki $M$. et al. Interleukin-6 receptor and signals. Chem Immunol 1992; 51: 181-204.

12 Taga T, Hibi M, Hirata Y, Yamasaki K, Yasukawa K, Matsuda $\mathrm{T}$, et al. Interleukin-6 triggers the association of Matsuda T, et al. Interleukin-6 triggers the association of
its receptor with a possible signal transducer, gp130. Cell its receptor with a

13 Novick D, Engelmann H, Wallach D, Rubinstein $M$ Soluble cytokine receptors are present in normal human urine. $\mathcal{E} \operatorname{Exp}$ Med 1989; 170: 1409-14

14 Honda $M$, Yamamoto S, Cheng M, Yasukawa K, Suzuki $\mathrm{H}$ Saito T, et al. Human soluble IL-6 receptor: Its detection and enhanced release by HIV infection. $\mathcal{F}$ Immunol 1992 148: $2175-80$.

15 Truelove SC, Witts LJ. Cortisone in ulcerative colitis. Final report on a therapeutic trial. $B M 7$ 1955; 2 : $1041-8$.

16 Myren J, Bouchier IAD, Watkinson G, Softley A, Clamp SE Dombal FT. The OMGE multinational inflammatory Dombal FT. The OMGE multinational inflammatory cases. Scand $f$ Gastroenterol 1984; 19 (suppl 95): 1-27.
17 Nakajima T, Yamamoto S, Cheng M, Yasukawa K, Hirano $\mathrm{T}$, Kishimoto $\mathrm{T}$, et al. Soluble interleukin-6 receptor is released from receptor-bearing cell lines in vivo. fpn $\mathcal{F}$ Cancer Res 1992; 83: 373-8.

18 Hirata $Y$, Taga $T$, Hibi $M$, Nakano $N$, Hirano $T$, Kishimoto T. Characterization of IL-6 receptor expression by monoclonal and polyclonal antibodies. $\mathcal{f}$ Immunol 1989; 143: 2900-6.

19 Yasukawa K, Saito T, Fukunaga T, Sekimoto Y, Koishihara $\mathrm{Y}$, Fukui $\mathrm{H}$, et al. Purification and characterization of soluble human IL 6 receptor expressed in $\mathrm{CHO}$ cells. f Biochem 1990; 108: 673-6.

20 Honda M, Kitamura K, Matsuda K, Yokota Y, Yamamoto $\mathrm{N}$, Mitsuyasu R, et al. Soluble IL-2 receptor in AIDS Correlation of its serum level with the classification of Correlation of its serum level with the classification of HIV-induced disease

21 Fernandez-Botran R. Soluble cytokine receptors. Their role in immunoregulation. FASEB f 1991; 5: 2567-74.

22 Rubin LA, Nelson DL. The soluble interleukin-2 receptor Biology, function, and clinical application. Ann Int Med 1990; 113: 619-27.

23 Seckinger $\mathbf{P}$, Isaaz S, Dayer JM. Purification and biologic characterization of a specific tumor necrosis factor a inhibitor. $\mathcal{F}$ Biol Chem 1989; 264: 11966-73.

24 Mackiewicz A, Rose-John S, Schooltink H, Laciak M, Górny A, Heinrich PC. Soluble human interleukin-6receptor modulates interleukin-6-dependent N-glycosylareceptor modulates interleukin- 6 -dependent $\mathrm{N}$-glycosyla-
tion of $\alpha 1$-protease inhibitor secreted by HepG 2 cells. tion of $\alpha 1$-protease inhibitor
FEBS Lett 1992; 306: 257-61.

25 Mackiewicz A, Schooltink H, Heinrich PC, Rose-John S Complex of soluble human IL-6-receptor/IL-6 upregulates expression of acute-phase proteins. $\mathcal{F}$ Immuno 1992; 149: 2021-7.

26 Yasukawa K, Futatsugi K, Saito T, Yawata H, Narazaki M, Suzuki H, et al. Association of recombinant soluble IL-6signal transducer, gp130, with a complex of IL-6 and IL-6 receptor, and establishment of an ELISA for soluble gp130. Immunol Lett 1992; 31: 123-30.

27 Hansen MB, Svenson M, Diamant M, Bendtzen K. Antiinterleukin-6 antibodies in normal human serum. Scand $\mathcal{F}$ Immunol 1991; 33: 771-81.

28 Takemura H, Suzuki H, Yoshizaki K, Ogata A, Yuhara T, Akama $\mathrm{T}$, et al. Anti-interleukin-6 autoantibodies in Akama T, et al. Anti-interleukin-6 autoantibodies in rheumatic diseases. Increased frequency in the sera of patients

29 Matsuda T, Hirano $T$, Nagasawa $S$, Kishimoto $T$. Identification of $\alpha 2$-macroglobulin as a carrier protein for IL-6. F Immunol 1989; 142: 148-52.

30 LaMarre J, Wollenberg GK, Gonias SL, Hayes A. Cytokine binding and clearance properties of proteinase activated $\alpha 2$-macroglobulins. Lab Invest 1991; 65: 3-14.

31 Mueller C, Knoflach P, Zielinski CC. T-cell activation in Crohn's disease. Increased levels of soluble interleukin-2 Crohn's disease. Increand in supernatants of stimulated peripheral blood mononuclear cells. Gastroenterology 1990; 98: 639-46. 